\title{
Effects of Corporate Governance on Banking Performance of Commercial Banks in Bangladesh
}

\author{
Mohammad Niaz Morshed \\ Department of Finance \\ Faculty of Economics and Management Sciences \\ International Islamic University Malaysia, 53100 Jalan Gombak, Kuala Lumpur, Malaysia \\ E-mail: tanbirbiu45@gmail.com \\ SMH Kabir (Corresponding Author) \\ Department of Business Administration \\ Faculty of Economics and Management Sciences \\ International Islamic University Malaysia, 53100 Jalan Gombak, Kuala Lumpur, Malaysia \\ E-mail: sardarmd.humayun.kabir@gmail.com
}

Md Muhibbullah

Department of Economics, Faculty of Economics and Management Sciences

International Islamic University Malaysia, 53100 Jalan Gombak, Kuala Lumpur, Malaysia

E-mail: muhibedu@gmail.com

Rafia Afroz

Department of Economics

Faculty of Economics and Management Sciences

International Islamic University Malaysia, 53100 Jalan Gombak, Kuala Lumpur, Malaysia E-mail: rafia@iium.edu.my 
Fadhilah Abdullah Asuhaimi

Department of Finance

Faculty of Economics and Management Sciences

International Islamic University Malaysia, 53100 Jalan Gombak, Kuala Lumpur, Malaysia

E-mail: fadhilahasuhaimi@iium.edu.my

Received: October 26, 2019

Accepted: December 18, 2019

Published: Jan. 18, 2020

doi:10.5296/ifb.v7i1.15710

URL: http://dx.doi.org/10.5296/ifb.v7i1.15710

\begin{abstract}
Corporate governance is the system by which organizations are directed, monitored and controlled. It is an oversight mechanism to ensure the management team efficiently allocates the organizational resources, so as to protect the interest of shareholders and stakeholders. There is a need for good corporate governance practice to stabilize the performance of financial institutions. This study investigated the influence of corporate governance in banking performance. Panel data analysis has been conducted for the top nine public and private commercial banks operating in Bangladesh for a period of 2009 to 2017. Board size, structure of internal audit committee and capital adequacy ratio were being taken as independent variables to measure the effects of corporate governance whereas return on asset, return on equity and earnings per share were being taken as dimensions for measuring bank performance. Correlation and regression analysis techniques were being used to examine the relationships between corporate governance practices and bank performance. The results indicated that CAR has the greater impact on Bank performance. The information derived from this study can be valuable and will help to enhance the understanding of the governing bodies of financial institutions for accelerating banking performance.
\end{abstract}

Keywords: Corporate Governance, Bank Performance, Bangladesh 


\section{Introduction}

The banking sector plays an important role in the financial system of a country. Research on bank performance is very relevant given its central tendency in today's economies. Corporate governance is the system by which banks are directed, monitored and controlled. Effective corporate governance in the financial institutes is a means of mobilizing the capital with the efficient utilization of the resources of the banks (Mayer, 1998). In other words, corporate governance promotes the efficient utilization of resources and the accountability of the resources utilized during the process (Cadbury, 2000). The Asian Development Bank (2000) considers the corporate governance as a bundle of instructions or mechanism which establishes the relationship amid the shareholders, administrators and management. The need for corporate governance arises from the conflict between the stakeholder and the company. The key objective of a corporation is to increase profit for its stakeholders whereas individuals serve for their own interest. And the job of governance is to align between the stakeholders and an individual. But, this job of corporate governance gets challenged when a financial crisis happens. During a financial crisis, instability can lead to a critical situation, as noted by Marinković \& Radović (2014). The financial crisis has an effect on banks' performance and can extend to other sectors.

In Bangladesh, the market capitalization is $6.5 \%$ of GDP, as the investors have low confidence due to the weak corporate governance (Sobhan \& Werner, 2003). Family businesses typically possess most of the private companies in Bangladesh. Therefore, there is an absence of an effective corporate governance system in financial institutes. Financing depends upon banks in Bangladesh rather than on the capital markets (Sobhan \& Werner, 2003). The controlled ownership by government and founding family members in the stock companies also causes set back to the corporate governance (Haque et al., 2011). The non-efficient markets and high concentration of ownership in the banking sector of Bangladesh leads to weak corporate governance (Temple, 2002).Recently, the banking sector of Bangladesh came under serious allegations where BDT 40 Billion credit default of Hallmark Group and BDT 2 Billion credit default of Bismillah Group were taken place by six commercial banks (Alam \& Akhter, 2017). Such incidents proved the gap in good corporate governance practices in the banks. According to the World Bank (2003), the accounting rules and practices are not enforced in the Bangladesh banking sector. Hence, there is a critical need of study on banking performance influenced by corporate governance. Iannotta et al. (2007) performed an integrated analysis considering corporate governance, particularly ownership structure, risk and performance. In this study, the focus is on the corporate governance factors that are adopted by banks, measuring bank performance, and studying the influence of corporate governance on bank performance. The lack of studies of the effect on bank performance also justified this study's relevance. In order to do so, the effects of board size, structure of internal audit committee and capital adequacy ratio has been considered. The evolution of banks' governance after crisis years has also been considered. 


\section{Literature Review}

\subsection{Bank Performance}

Banks have an important role in the countries financial growth and they engage control over the supply of money in circulation for the fundamental improvements of monetary benefit. The banking sector gives a huge portion of the medium of exchange and is the essential instrument through which fiscal arrangement is led in terms of their deposit preparation and loaning tasks. Banks encourage the beneficial use of ideal money, hence helping society to create assets. The term "bank performance" signifies conveying into execution or accomplishment; or achievement of explicit exercises, or the execution of an endeavour of an obligation. Bank performance might be characterized as the impression of the manner by which the assets of a bank are utilized in a structure that empowers it to accomplish its destinations. Besides, the term bank performance implies the appropriation of a set of indicators which are demonstrative of the bank's present status and the degree of its capacity to accomplish the main objectives. Previous studies have mostly investigated the connection between corporate governance and bank performance by using Tobin's $Q$ or other market performance measures. But, in this study, the operating performances of Bangladeshi banks are focused. The fundamental reason is that market measures, i.e. stock costs and market capitalizations are not accessible for the investigated banks. Additionally, capital market of Bangladesh is not productive and stable. Therefore, market-based data may not precisely correspond to the performance of Bangladeshi banks. As supported by Bhagat and Bolton (2008), stock returns are not in every case fundamentally connected with governance, regardless of whether there is a noteworthy relationship among corporate governance and bank performance. In addition, the expanded multifaceted nature of financial institute requires thinking about the particular drivers of banking performance regarding income and efficiencies. Previous studies used return on asset (ROA), return on equity (ROE) and earnings per share (EPS) as the measures of firm's performance (Brick et al., 2006; Cheng, 2008; Jackling and Johl, 2009; Brown and Caylor, 2006; Klein, 1998; Lo, 2003). ROA indicates the actual performance of a firm (Ponnu, 2008). ROE is another predictor for performance measure and appropriate both inshort-term and long-term benefits for most shareholders (Johnson \& Greening, 1999; Brealey \& Myers, 2000). It demonstrates a financial saver about how much benefit can be formed by the firm, utilizing the cash contributed from its investors (Epps \& Cereola, 2008). EPS sanction the partners to realize overall increase earned on per share basis which decides benefit (Weygandt et al., 2010). Therefore, in this study, the investigation utilizes ROA, ROE and EPS to determine performance of banks.

\subsection{Corporate Governance}

Corporate governance can be market based or the bank centred relationship based. In the market based corporate governance, financing is provided by the investors while in the bank cantered corporate governance, financing comprises of a large portion of debt as well as equity (Prowse, 1996). Macey and Miller (1995) defined Corporate Governance as the regulations that give rights to the stockholders, members of the board and executives in 
management of the companies and financial institutions. Kraft and Tirtiroglu (1998) defined Corporate Governance as regulations comprising of rules, procedures and values that are implemented by shareholders, executive directors and the top management of the companies in performing tasks, transactions and functioning. As stated by Uddin (2005), lack of professional ethics by the governing bodies and ineffective policy implementation leads to poor corporate governance. On the other side, good corporate governance will in general guarantee sound corporate performance by giving assurance to investor's premium (OECD, 2004). Monetary pros and banks will be progressively anxious to place their money in firms with incredible administration since they will go up against lower costs of capital, which is another reason for better firm execution (Coombes \& Watson 2000). Various partners, including agents and suppliers, will likewise should be connected with and start a new business organization with so much firms, as the associations are most likely going to be progressively prosperous, increasingly alluring, and reliable than those with firms with less reasonable administration.

\subsection{Banking Sector of Bangladesh}

In Bangladesh, there are few professional bodies that carry out audit in companies according to the Bangladesh Accounting Standards (BAS). There are 57 scheduled banks and 6 non-scheduled banks in Bangladesh that operate under the Central Bank, called Bangladesh Bank. According to Kamal et al. (2007), the banking sector acts as a main monetary intermediary in the economic activities of Bangladesh because of the weak capital markets, inadequate accessibility of financial tools as well as the absence of the self-confidence in the economic system of Bangladesh. A bank also plays an intermediary role to provide constancy to monetary organizations. Bangladesh as a country like several other developing nations have implemented policies for developing and restructuring the banking sector. A significant characteristic of these policies is the designing of regulations, rules and practices that can govern and monitor the transactions going on in the banking sector. These practices are known as corporate governance of the banks. The bank centred corporate governance is suited for Bangladesh as the financial markets are mostly undeveloped emerging markets (Arun \& Turner, 2004). So, banks are the major source of finance in the economy. According to Moudud (2015), the Conventional-Banks and the Shariah Banks are using corporate governance guidelines and regulations, as both the banking sectors are facing significant improvement in their functioning. As compared to the Conventional Banks, the Shariah based Banks have lacking in following the Corporate Governance applies (Moudud, 2015). The Corporate Social responsibility in the banking sector of Bangladesh focuses on the initiatives that are taken in order to assist two vital sectors within the economy of Bangladesh, that is, the agriculture sector and the Small Medium Enterprise sector (Wise \& Ali, 2009).

\subsection{Financial Crisis}

Strong Corporate Governance will enhance the efficiency of the economy in Bangladesh. The Bangladesh banking sector would become competitive if good Corporate Governance would be implemented in financial institutions. For attracting foreign investment, there is a need that Bangladesh should improve its corporate governance system. Followings are the cases of 
major corporate collapses that occurred throughout the world: The first ever-recorded case in the history of the banking sector was that of the Medici Bank in 1494 in Italy (Raymond, 1948). The bank ended up in large debts due to the inability of the bank to control lavish spending of the directors and managers. As a result, the bank underwent bankruptcy. In 1983, the Carrian Group, a Hong Kong conglomerate, which was the largest in the history of Hong Kong has been collapsed. This group owned real estate business and other businesses such as insurance, hotels, transport, taxi, and so on (Cromie, 1986). It occurred due to an accounting fraud. In this case, an auditor was murdered, and an advisor committed suicide. In 1987, the American oil subsidiary Chevron Corporation, Texaco Inc. went into bankruptcy after undergoing a legal battle with the Pennzoil (Tierney, 2007). It owed a debt of $\$ 10.5$ billion. Later, Chevron Corporation resurrected and took over the company. In 2009, after the financial crisis of 2007 to 2008, the government of Ireland forced the Anglo-Irish bank to be nationalized. The total loans granted to the directors were higher than $€ 255$ million (Carolan, 2009). The private investors sued the bank for $\$ 23$ million. In 2001, Enron scandal emerged as a result of the corruption in the Enron Corporation, which is an American energy, commodities and services-based corporation (Gore \& Murthy, 2011). This scandal questioned the accounting rules and practices on several corporations in the United Sates. Hallmark is the largest banking deception in Bangladesh's banking sector. It occurred to the weak Corporate Governance system in the banking industry of Bangladesh. The Sonali Bank of Bangladesh was involved in giving a loan of USD 318 million to the Hallmark group (Joseph, 2016). The fraud was detected in 2012 and the top management of the Sonali Bank was found to be involved in the corruption. Proper implementation of corporate governance rules and regulations would have prevented the above cases of fraud and corruption. Hence, this shows that there is a dire need that companies and banks should strictly implement the corporate governance rules and regulations in order to comply with the international standards. This will prevent cases of fraud and will also attract foreign investors.

\subsection{Relationship Between Corporate Governance and Bank Performance}

Previous studies have stated that practicing good corporate governance helps to improve organizational performance under steady economic conditions and protects against the adverse effects of financial crises and turbulence (Beltratti \& Stulz, 2012; Erkens et al., 2012; Gupta et al., 2013; Jackowicz \& Kowalewski, 2012). In this study, the following corporate governance dimensions are used: board size, structure of audit committee and capital adequacy standard ratio. The size of the board indicates the number of administrators in the panel. There are various remarks about the size of the 'perfect' board. A perfect board ought to participate with individuals who are official and not official (Ghosh, 2003) 8 to 9 people ought to be ready (Lipton and Lorsch, 1992) while Leblanc and Gillies (2003) likewise expressed that size of board should be between 8 to 11 individuals. BEI (2004) rules show that internationally successful corporate sheets have relationship of seven to fifteen chiefs. As indicated by BSEC (2012), the size of the Board Members of the organizations should be between 5 and 20. Viable board size ought to be included different skill and investment to give a well-shaped board. An excessive number of individuals in the top managerial staff might be wasteful because of futile correspondence that causes the chiefs' free riding issue. 


\section{Ml Macrothink}

Instead of number, viability of a board ought to be the most extreme thought. Participation of free chiefs empowers the board to take fair-minded and fair-minded choice. The BSEC (2012) stipulates that in any event one fifth of the all-out number of executives of the Board of Directors ought to be free. Consequently, supervisors will be increasingly autonomous to take the choice which will expand the imagination of administrators (Gande et al., 2008). The Audit Committee (AC) examinations internal money related activities, grows the exemplary nature of budgetary reports, and indorses a choice of outside evaluators and checking the inspectors qualities and objectivity just as review productivity which causes an organization to accomplish its aspirations in a powerful and efficient manner (Subramaniam et al., 2013).

The fundamental objective of setting up an Audit advisory group is to keep up the uprightness of monetary reports by reflecting money related material of organizations and present a valid just as reasonable view (Ojo, 2006). Inward review underpins organization and the executives in the gainful after-effect of their duty (Lorsch \& Young, 1990). Review advisory group helps the leading group of the executives, organization, inner-review and outside-review, a ton to take the significant choice about firm. One of the most significant markers of good administration practice is the capital sufficiency proportion (least legitimate necessity) that exhibits the long-haul endurance limit of the undertaking. It additionally diminishes the probability of insolvency of banks (Yudistira, 2003). It is utilized to secure contributors and to improve the dependability and productivity of monetary frameworks on the planet. So as to ingest the misfortunes and monetary inadequacies of the Bank, the Bank may give the Bank's capital sufficiency and give insurance and affirmation to contributors and loan bosses. Great corporate administration will in general give solid corporate execution by giving security to the interests of investors (OECD, 2004). Stockholders and lenders will be more enthusiastic to invest on companies with decent governance because they will confront less capital costs, which are a better firm performance source (Coombes \& Watson, 2000). Additional shareholders, as well as personnel and sellers, will want to engage in business relationships and involve in relationships with such firms because their relationships are more prosperous, more equitable and more durable than companies with less effective governance.

\subsection{Research Framework}

Based on the literature review, the following conceptual framework has been developed in Figure 1 to guide this research. 


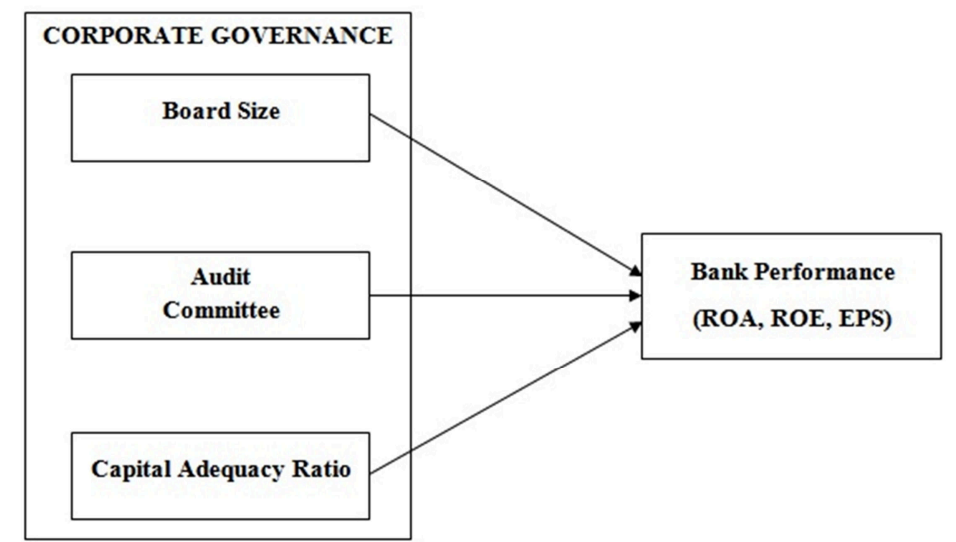

Figure 1. Research framework

\section{Methods}

In this study, the proposed conceptual framework adapted from agency theory. The basic concept of agency theory was first established by Jensen and Meckling (1976) and then reviewed by Eisenhardt (1989) to introduce the concept, context, and principles of the theory. This theory presents a model to analyse the relationships between variables for identifying the problem that exists between parties and methods to solve it (Eisenhardt, 1989). In this study, the agency relationship occurs when the principal party (the banks) depends on the other party (the agent) to perform certain actions on behalf of the client.

The current research comprises of quantitative research methodology. The quantitative research includes secondary sources of data collection. The secondary source includes review of literature from books, articles, journals and data from the authentic websites of Bangladesh bank, Dhaka Stock Exchange and Bangladesh Securities and Exchange Commission and Bank's annual report. The target population for this study was all banks working in Bangladesh. Panel data analysis technique has been employed for the investigation (Zakaria et al., 2014). The time considered for this paper is 9 years from 2009 to 2017. This period is soon after the budgetary emergency of 2008-09, which critically affected monetary organizations (Beltratti \& Stulz, 2012; Gorton \& Metrick, 2012). Among the populace nine banks are taken as a sample to break down the effect of corporate governance on bank performance. These nine sample banks are Sonali Bank, Agrani Bank, Pubali Bank, Rupali Bank, Islami Bank Bangladesh Limited, Dutch-Bangla Bank Limited, Prime Bank Limited, Dhaka Bank Limited, and BRAC Bank Limited. The yearly reports of these banks are investigated by downloading from the official sites of the respective banks. The reason for choosing the yearly reports is that the yearly report is the most widely recognized document normally created by organizations in Bangladesh. Annual reports are considered as the main way of communicating information about the company (Belal, 2000; Khan et al., 2009).

From the dataset, to quantify the effect of corporate governance on bank performance, three models has been produced where ROA, ROE and EPS are taken as measurements for bank 
performance (dependent variable) and size of the Board of the individual banks (BDS), size of the audit committee (AC) and capital adequacy ratio (CAR) are taken as independent variables. In this investigation three regression models has been taken to decide the effect of the corporate governance on bank performance. Here $\beta$ is the constant and $\varepsilon$ is the error.

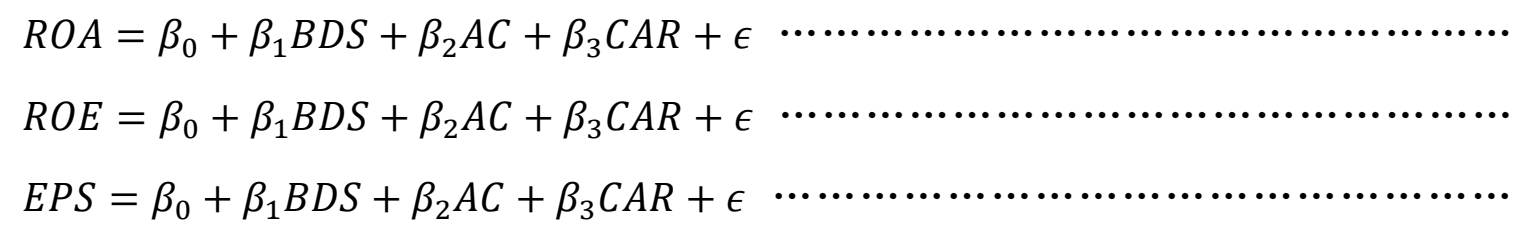

Statistical analysis tool was utilized to assess and inspect the information to gauge the connection between corporate administration and bank execution. This examination has utilized two techniques for investigation, to be correlation and regression investigation, to analyze the connection among dependent and independent variables. Finally, some managerial implications are recommended at the end based on panel data regression analysis results.

\section{Analysis and Results}

Generalized least squares estimator with Durbin-Watson residual test has been considered during the linear regression analysis to correct the standard errors for possible autocorrelation. The correlation coefficients give explanation of the strength of the relationship and the course of the relationship (can be positive or negative) with two continuous variables. It's range from -1 to +1 and -1 indicates strong negative correlation while +1 indicates strong positive correlation. So, the closer the coefficient of these numbers represents the strong correlation of the data. This scale indicates no correlation at 0 , so the value closest to zero emphasizes a weaker correlation than those close to $+1 /-1$. Bank Performance is calculated by three dependent variables; Return on Asset (ROA), Return on Equity (ROE) and Earnings per share (EPS).

From Table 1, it is found that Board Size (BDS) has the negative relationship with ROA $(-0.007)$ and the $\mathrm{p}$-value is 0.954 which is more than 0.05 . Therefore, it indicates that there is no relationship between BDS and ROA. On the other hand, the correlation coefficient BDS with ROE and EPS is 0.001 and 0.002 respectively and significance level of $p=0.995$ and $\mathrm{p}=0.986$ which is more than 0.05 . It indicates that BDS has the positive but very weak relationship with ROA and ROE. According to the correlation test, BDS does not affect that much on the Bank performance. The correlation coefficient of Audit Committee (AC) and ROA is 0.020 and the p-value is 0.862 which is more than 0.05 , this means there is a weak positive relation between $\mathrm{AC}$ and ROA. In contrast, the correlation coefficient of $\mathrm{AC}$ with ROE and EPS is -0.117 and -0.103 and p-value is 0.300 and 0.359 respectively which is not significant. It means the number of members of Audit Committee (AC) is inversely proportional to banks' ROE and EPS. The positive values of correlation coefficient of Capital Adequacy Ratio(CAR) with ROA (0.501) and with ROE (0.679) and with EPS (0.641) 
indicates that there is a moderate positive relationship exist between CAR and Bank performance (calculated by ROA, ROE and EPS) and the $p$ value is $(0.000,0.000,0.000$ respectively). It indicates that $\mathrm{CAR}$ affects the Bank performance.

Table 1. Correlation results

\begin{tabular}{lllll}
\hline Variables & Tests & $\begin{array}{l}\text { Return on } \\
\text { Asset }\end{array}$ & $\begin{array}{l}\text { Return on } \\
\text { Equity }\end{array}$ & $\begin{array}{l}\text { Earnings } \\
\text { per Share }\end{array}$ \\
\hline \multirow{2}{*}{ Board Size } & Correlation Coefficient & -0.007 & 0.001 & 0.002 \\
& Sig. (2-tailed) & 0.954 & 0.995 & 0.986 \\
\hline \multirow{2}{*}{ Audit Committee } & Correlation Coefficient & 0.020 & -0.117 & -0.103 \\
& Sig. (2-tailed) & 0.862 & 0.300 & 0.359 \\
\hline Capital Adequacy & Correlation Coefficient & 0.501 & 0.679 & 0.641 \\
Ratio & Sig. (2-tailed) & 0.000 & 0.000 & 0.000 \\
\hline **Correlation is significant at the 0.01 level (2-tailed) & & & \\
$*$ Correlation is significant at the 0.05 level (2-tailed) & & & \\
\end{tabular}

In Table 2, the results are from the multiple regression Model 1. These results are based on dependent variable ROA. It can be seen from the results of regression analysis that the dependent variable describes the illustrative variables in the model with $\mathrm{R}^{2}=26.7 \%$ and Adjusted $\mathrm{R}^{2}=23.9 \%$ which indicates the independent variables simplify $26.7 \%$ of volatility of the dependent variable. The result of $F$ is 9.537 also significant with the p-value $=0.000$, which indicates that corporate governance does not sufficient effect on ROA and regresses in the model have described variations appropriately in the dependent variable. Therefore, ROA has positive and significant relationship with capital adequacy ratio, but there is no relation with audit committee and board size.

Table 2. Regression Analysis; Dependent Variable: Return on Asset (ROA)

\begin{tabular}{|c|c|c|c|c|c|}
\hline \multirow[t]{2}{*}{ Model 1} & \multicolumn{2}{|c|}{$\begin{array}{l}\text { Unstandardized } \\
\text { Coefficients }\end{array}$} & \multirow{2}{*}{$\begin{array}{l}\text { Standardized } \\
\text { Coefficients } \\
\text { Beta }\end{array}$} & \multirow[t]{2}{*}{$\mathbf{t}$} & \multirow[t]{2}{*}{ Sig. } \\
\hline & $\mathbf{B}$ & Std. Error & & & \\
\hline (Constant) & -1.362 & 0.623 & & -2.185 & 0.032 \\
\hline Board Size & -0.02 & 0.023 & -0.091 & -0.861 & 0.392 \\
\hline Audit Committee & 0.13 & 0.105 & 0.132 & 1.234 & 0.221 \\
\hline Capital Adequacy Ratio & 0.179 & 0.034 & 0.527 & 5.292 & 0.000 \\
\hline
\end{tabular}

In Table 3, dependent variable is ROE for Model 2. It can be seen from the results of regression analysis that the dependent variable describes the illustrative variables in the model with $\mathrm{R}^{2}=46.4 \%$ and Adjusted $\mathrm{R}^{2}=44.3 \%$ which indicates the independent variables simplify $46.4 \%$ of unpredictability of the dependent variables. The result of $\mathrm{F}$ is 9.537 also significant with the $\mathrm{p}$-value $=0.000$. This specifies that, in general, the model can significantly forecast the dependent variable and corporate governance does not have that much influence 
on ROE. The results also show that there is a positive relationship between ROE and capital adequacy ratio and other variables do not have any relation with ROE.

Table 3. Regression Analysis; Dependent Variable: Return on Equity (ROE)

\begin{tabular}{llllll}
\hline \multirow{2}{*}{ Model 2 } & \multicolumn{2}{l}{$\begin{array}{l}\text { Unstandardized } \\
\text { Coefficients }\end{array}$} & $\begin{array}{l}\text { Standardized } \\
\text { Coefficients }\end{array}$ & \multirow{2}{*}{ t } & \multirow{2}{*}{ Sig. } \\
\cline { 2 - 5 } & B & Std. Error & Beta & -4.064 & 0.000 \\
\hline (Constant) & -72.492 & 17.839 & & -0.547 & 0.586 \\
Board Size & -0.36 & 0.658 & -0.049 & 0.042 & 0.967 \\
Audit Committee & 0.125 & 3.004 & 0.004 & 8.023 & 0.000 \\
Capital Adequacy Ratio & 7.769 & 0.968 & 0.683 & & \\
\hline
\end{tabular}

$\mathrm{R}=0.681, \mathrm{R}^{2}=0.464$, Adjusted $\mathrm{R}^{2}=0.443$, Anova, $\mathrm{sig}=0.000, \mathrm{~F}=22.2$

In Table 4, dependent variable is CAR for Model 3. It can be seen from the results of regression analysis that the dependent variable describes the illustrative variables in the model with $\mathrm{R}^{2}=41.3 \%$ and Adjusted $\mathrm{R}^{2}=39 \%$ which indicates the independent variables simplify $41.3 \%$ of unpredictability of the dependent variables. The result of $\mathrm{F}$ is 18.046 also significant with the $\mathrm{p}$-value $=0.000$. This specifies that, in general, the model can significantly forecast the dependent variable. The results from the Table 4 also shows that EPS has the positive relation with the capital adequacy ratio and again EPS has no relationship with Board size and audit committee.

Table 4. Regression Analysis; Dependent Variable: Earnings per Share (EPS)

\begin{tabular}{llllll}
\hline \multirow{2}{*}{ Model 3 } & \multicolumn{2}{l}{$\begin{array}{l}\text { Unstandardized } \\
\text { Coefficients }\end{array}$} & $\begin{array}{l}\text { Standardized } \\
\text { Coefficients }\end{array}$ & \multirow{2}{*}{ t } & \multirow{2}{*}{ Sig. } \\
\cline { 2 - 4 } & B & Std. Error & Beta & & \\
\hline (Constant) & -103.218 & 24.909 & & -4.144 & 0.000 \\
Board Size & -0.453 & 0.919 & -0.047 & -0.493 & 0.624 \\
Audit Committee & 0.462 & 4.195 & 0.011 & 0.110 & 0.913 \\
Capital Adequacy Ratio & 9.798 & 1.352 & 0.646 & 7.246 & 0.000 \\
\hline
\end{tabular}

$\mathrm{R}=0.643, \mathrm{R}^{2}=0.413$, Adjusted $\mathrm{R}^{2}=0.390$, Anova, $\mathrm{sig}=0.000, \mathrm{~F}=18.046$

\section{Discussion}

Based on the corporate governance practices of the nine of the largest banks of Bangladesh and using 81 observations for the time period of 2009-2017, this study investigated the relationship between corporate governance and Bank performance. According to the regression analysis, it is clear that board size of Banks has no relationship with ROA, ROE and EPS. Therefore, the association between BDS and bank performance is questionable. Consequently, bank should emphasize on the productive and efficient directors than the size of the Board. The results from the regression also demonstrate that there is no relationship between the number of account committee members and the bank performance. The 
proficiency of auditor can carry out more in real deception uncovering than size of the committee. In addition to the professional skills, AC members should be self-governing equally to the employees and operative sector. The total number of independently working directors in the board and the total number of individual members in the audit committee need to be balanced. Their competency and effectiveness need to be the ultimate consideration rather than focusing on their numbers. The findings from the regression imply that, capital adequacy ratio has the positive and significant relation with ROA, ROE, and EPS. That means the CAR has the greater impact on Bank performance. So, it can be concluded that all banks should maintain their capital adequacy ratio which will attract clients and reduce the chances of becoming insolvent as well as will increase the performance of the bank. Banks can set their own policies regarding capital adequacy ratio based on the expected safety level.

Directors are accountable for the management of their companies. Shareholders can actively participate in establishing good governance practices to hold performance of the banks parallel to central bank. The role of stakeholders in governance is to determine that there is an appropriate board of directors, managers and auditors are being employed. It gains the confidence of the local as well as foreign investors as they feel satisfied that their investment is in safe hands. Good corporate governance also ensures the implementation of the legal compliance and unbiased decisions for the benefit of the companies. Good corporate governance gives the impression to the investors that the financial institutions are stabilized, and it is safe to invest in them even during financial crisis.

\section{Conclusion and Recommendations}

In Bangladesh, the corporate governance in Banks \& financial institutions is highly linked with the performance of the companies. This study will help the Banks and other financial institutions about following good corporate governance practices. A failure of governance in banking and financial institutions is one of the causes of bankruptcy by reputed companies. This is because organizations require funds either from banking channel or capital market. So, in order to pursue the target and short-term profit maximization set by the Board, banks and financial institutions engaged in malpractices and results in loan default, bankruptcy, and finally financial collapse. The Capital Market of Bangladesh is still in an emerging stage with market capitalization of amounting 6.5\% GDP. Most importantly, the country achieved such growth within many constraints like political hurdles, import dependency and infrastructure bottlenecks. The size of the economy (GDP) has been tripled to USD 221.4 billion (FY2016-17) in the last decade, while the service sector, especially the banking sector made visible contribution both directly and indirectly in real sector growth.

There were some limitations in this study. Firstly, this study conducted only on the banking sector of Bangladesh. So, further research can be conducted on other financial institutions like, insurance companies, NGO, pension funds and so on. Secondly, this study focuses on the time period after the financial crises of 2007-2008. Therefore, further study can be the comparison of the before and after financial crisis. Finally, this study has taken three variables - size of the board, size of the audit committee and capital adequacy ratio to 
conclude the performance of the banks in the course of return on asset, return on equity and earnings per share. There are still many variables like, the structure of ownership, loan loss ratio, $\mathrm{P} / \mathrm{E}$ ratio, and risk variables which can be used to investigate the relation between corporate governance and Bank performance.

\section{References}

Alam, M. R., \& Akhter, F. (2017). Impact of corporate governance on performance of commercial banks in Bangladesh. The Cost and Management, 45(4), 2-9.

Arun, T. G., \& Turner, J. D. (2004). Corporate governance of banks in developing economies: Concepts and issues. Corporate Governance: An International Review, 12(3), 371-377.

Asian Development Bank (ADB). (2000). Promoting good governance: ADB's Medium-term Agenda and Action Plan. Asian Development Bank Board Paper.

Bangladesh Enterprise Institute (BEI). (2004). The code of corporate governance for Bangladesh: principles and guidelines for best practices in the private sector, financial institutions, state-owned enterprises and non-governmental organizations. Task Force on Corporate Governance, 1-85.

Belal, A. R. (2000). Environmental reporting in developing countries: empirical evidence from Bangladesh. Eco - Management and Auditing: The Journal of Corporate Environmental Management and Auditing, 7(3), 114-121.

Beltratti, A., \&Stulz, R. M. (2012). The credit crisis around the globe: Why did some banks perform better?. Journal of Financial Economics, 105(1), 1-17.

Bhagat, S. and Bolton, B. (2008). Corporate governance and firm performance. Journal of Corporate Finance, 14(2), 257-273.

Brealey, R. A., \& Myers, S. (2000). Principles of corporate finance. New York: Irwin McGraw-Hill.

Brick, I. E., Palmon, O., \& Wald, J. K. (2006). CEO compensation, director compensation, and firm performance: Evidence of cronyism?. Journal of Corporate Finance, 12(3), 403-423.

Brown, L. D., \& Caylor, M. L. (2006). Corporate governance and firm valuation. Journal of accounting and public policy, 25(4), 409-434.

BSEC. (2012). Status of compliance with the conditions imposed by Bangladesh Securities and Exchange Commission's Notification No. SEC/CMRRCD/2006-158/134/Admin/44 dated 07 August 2012.

Cadbury, S. A. (2000). The corporate governance agenda. Corporate Governance: An International Review, 8(1), 7-15.

Carolan, M. (2012). Investors sue Anglo for \$23 m. Irish Times. November, 2.

Cheng, S. (2003). Time to revamp'insiderboards'. National Real Estate Investor, 45(1), 72. 
Coombes, P., \& Watson, M. (2000). Three surveys on corporate governance. McKinsey Quarterly, (4), 75-78.

Cromie, A. (1986). Carrian fraud trial opens in Hong Kong. The Sydney Morning Herald.

Eisenhardt, K. M. (1989). Building theories from case study research. Academy of management review, 14(4), 532-550.

Epps, R. W., \&Cereola, S. J. (2008). Do institutional shareholder services (ISS) corporate governance ratings reflect a company's operating performance?. Critical Perspectives on Accounting, 19(8), 1135-1148.

Erkens, D. H., Hung, M., \& Matos, P. (2012). Corporate governance in the 2007-2008 financial crisis: Evidence from financial institutions worldwide. Journal of corporate finance, 18(2), 389-411.

Gande, A., John, K., \&Senbet, L. W. (2008). Bank incentives, economic specialization, and financial crises in emerging economies. Journal of International Money and Finance, 27(5), 707-732.

Ghosh, A. (2003). Board structure, executive compensation and firm performance in emerging economies: Evidence from India. Indira Gandhi Institute of Development Research Working Paper, 91-9819090266.

Gore, M., \& Amol, G. (2013). A case of corporate deceit: Scientific e-journal of Management Science, 8(7), 3-38.

Gorton, G., \&Metrick, A. (2012). Securitized banking and the run on repo. Journal of Financial economics, 104(3), 425-451.

Gupta, K., Krishnamurti, C., \&Tourani-Rad, A. (2013). Is corporate governance relevant during the financial crisis?. Journal of International Financial Markets, Institutions and Money, 23, 85-110.

Haque, F., Arun, T., \& Kirkpatrick, C. (2011). The political economy of corporate governance in developing economies: The case of Bangladesh. Research in International Business and Finance, 25(2), 169-182.

Iannotta, G., Nocera, G., \&Sironi, A. (2007). Ownership structure, risk and performance in the European banking industry. Journal of Banking \& Finance, 31(7), 2127-2149.

Jackling, B., \&Johl, S. (2009). Board structure and firm performance: Evidence from India's top companies. Corporate Governance: An International Review, 17(4), 492-509.

Jackowicz, K., \&Kowalewski, O. (2012). Crisis, internal governance mechanisms and pension fund performance: Evidence from Poland. Emerging Markets Review, 13(4), 493-515.

Jensen, M. C., \&Meckling, W. H. (1976). Theory of the firm: Managerial behavior, agency costs and ownership structure. Journal of financial economics, 3(4), 305-360. 
Johnson, R. A., \& Greening, D. W. (1999). The effects of corporate governance and institutional ownership types on corporate social performance. Academy of management journal, 42(5), 564-576.

Joseph, A. (2016). Bangladesh's other banking scam. The New York Times. April 11.

Kamal, Y., Pervin, T., \&Alam, S. (2007). Corporate Governance in the Banking Sector of Bangladesh. The Bangladesh Accountant, 57(30), 73-81.

Khan, H. U. Z., Halabi, A. K., \&Samy, M. (2009). Corporate social responsibility (CSR) reporting: a study of selected banking companies in Bangladesh. Social responsibility journal, 5(3), 344-357.

Klein, A. (1998). Firm performance and board committee structure. The Journal of Law and Economics, 41(1), 275-304.

Kraft, E. \&Tirtiroglu, D. (1998). Bank efficiency in Croatia: A stochastic-frontier analysis. Journal of Comparative Economics, 26(2), 282-300.

Leblanc, R., \& Gillies, J. (2003). The coming revolution in corporate governance. Ivey Business Journal Online, 68(1), 1-12.

Lipton, M., \& Lorsch, J. W. (1992). A modest proposal for improved corporate governance. The business lawyer, 48, 59-77.

Lo, K. (2003). Economic consequences of regulated changes in disclosure: The case of executive compensation. Journal of Accounting and Economics, 35(3), 285-314.

Lorsch, J., \& Young, J. (1990). Pawns or potentates: The reality of America's corporate boards. Academy of Management Perspectives, 4(4), 85-87.

Macey, J. R. \& Miller, G. P. (1995). Corporate governance and commercial banking: A comparative examination of Germany, Japan and the United States. Stanford Law Review, 48, 73-112.

Marinković, S., \&Radović, O. (2014). Bank net interest margin related to risk, ownership and size: an exploratory study of the Serbian banking industry. Economic research-Ekonomskaistraživanja, 27(1), 134-154.

Mayer, C. (1998). Financial systems and corporate governance: a review of the international evidence. Journal of Institutional and Theoretical Economics (JITE)/Zeitschriftfür die gesamteStaatswissenschaft, 154, 144-165.

Moudud, U. H. S. (2015). Corporate governance practices in Bangladesh: A comparative analysis between conventional banks and Islamic banks. International Journal of Management and Business Research, 5(1), 53-60.

Ojo, M. (2006). Auditor independence-its importance to the external auditor's role in banking regulation and supervision. In Published in the 2006 Conference Proceedings of the IBFR Conference, Costa Rica and Elsevier Journals. 
Organization for Economic Co-operation and Development (OECD). (2004). The OECD Principles of corporate governance. OECD Publications Service, France.

Ponnu, C. H. (2008). Corporate governance structures and the performance of Malaysian public listed companies. International Review of Business Research Papers, 4(2), 217-230.

Prowse, S. D. (1996). Corporate finance in international perspective: Legal and regulatory influences on financial system development. Economic and Financial Policy Review, Federal Reserve Bank of Dallas, QIII, 2-15.

Raymond, A. D. (1948). The Medici Bank: Its Organization, Management and Decline. New York University Press.

Sobhan, E. F., \& Werner, W. (2003). A comparative analysis of corporate governance in South Asia: Charting a roadmap for Bangladesh. A research project paper published by Bangladesh Enterprise Institute.

Subramaniam, N., Stewart, J., Ng, C., \& Shulman, A. (2013). Understanding corporate governance in the Australian public sector: A social capital approach. Accounting, Auditing \& Accountability Journal, 26(6), 946-977.

Temple, F. (2002). Strengthening Public Financial Accountability in Bangladesh. Institute of Chartered Accountants Bangladesh.

Tierney, D. (2007). American men, American oil, American arms. FDR and Spanish Civil War: Neutrality and Commitment in the Struggle that Divided America.Duke University Press.

Uddin, S. (2005). Privatization in Bangladesh: The emergence of 'family capitalism'. Development and Change, 36(1), 157-182.

Weygandt, J. J., Kimmel, P. D., Kieso, D., \& Elias, R. Z. (2010). Accounting principles. Issues in Accounting Education, 25(1), 179-180.

Wise, V., \& Ali, M. (2009). Corporate governance and corporate social responsibility in Bangladesh with special reference to commercial banks. American International University-Bangladesh Bus Econ Working Paper Series. Working Paper No. AIUB-BUS-ECON-2009-05

World Bank. (2003). Report on the Observance of Standards and Codes Bangladesh: Accounting and Auditing. The World Bank Report. May 16, 2003.

Yudistira, D. (2003). The impact of bank capital requirements in Indonesia. Department of Economics, Loughborough, 1-9.

Zakaria, Z., Purhanudin, N., \&Palanimally, Y. R. (2014). Board governance and firm performance: A panel data analysis. Journal of Business Law and Ethics, 2(1), 1-12. 


\section{Copyrights}

Copyright for this article is retained by the author(s), with first publication rights granted to the journal.

This is an open-access article distributed under the terms and conditions of the Creative Commons Attribution license (http://creativecommons.org/licenses/by/4.0/). 